\title{
Machines à convertir. Les magnétophones transmettent la voix des morts
}

\section{Christine Bergé}

\section{(2) OpenEdition \\ 1 Journals}

Édition électronique

URL : https://journals.openedition.org/tc/709

DOI : $10.4000 /$ tc.709

ISSN : 1952-420X

Éditeur

Éditions de l'EHESS

\section{Édition imprimée}

Date de publication : 1 novembre 1992

ISSN : 0248-6016

\section{Référence électronique}

Christine Bergé, " Machines à convertir. Les magnétophones transmettent la voix des morts »,

Techniques \& Culture [En ligne], 17-18 | 1992, mis en ligne le 10 janvier 2006, consulté le 29 septembre 2022. URL : http://journals.openedition.org/tc/709 ; DOI : https://doi.org/10.4000/tc.709

Ce document a été généré automatiquement le 29 septembre 2022.

Tous droits réservés 


\section{Machines à convertir. Les magnétophones transmettent la voix des morts}

Christine Bergé 